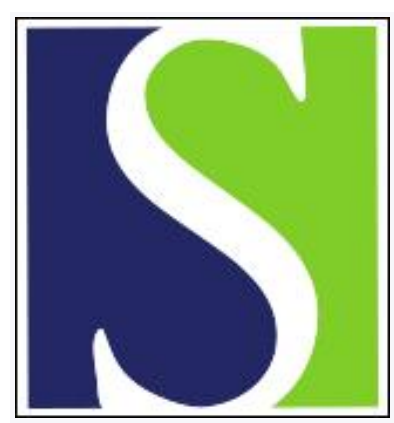

Scand J Work Environ Health 1985;11(4):281-286

https://doi.org/10.5271/sjweh.2228

Issue date: Aug 1985

Subjective symptoms among dental technicians exposed to the monomer methyl methacrylate.

by Rajaniemi R, Tola S

This article in PubMed: www.ncbi.nlm.nih.gov/pubmed/2932795

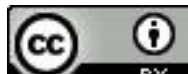




\title{
Subjective symptoms among dental technicians exposed to the monomer methyl methacrylate
}

\author{
by Risto Rajaniemi, DDS, ${ }^{1}$ Sakari Tola, $\mathrm{MD}^{2}$
}

\begin{abstract}
RAJANIEMI R, TOLA S. Subjective symptoms among dental technicians exposed to the monomer methyl methacrylate. Scand J Work Environ Health 11 (1985) 281-286. Dental technicians, their technical aids, and the students of the State Institute for Dental Technicians during a single academic year were surveyed for their use of the acrylic ester monomer and subjective symptoms in a questionnaire study. The population under study included all the members of the trade union in the greater Helsinki area and all specially trained techniral aids in Finland. Acrylic monomers were handled daily without skin protection by $81 \%$ of the 293 respondents. Current hand dermatitis, or previous local dermatological problems, was reported by $17 \%$ of the respondents. Frequent contact with the acrylic monomer increased the rate of the self-reported dermatitis. The symptoms were spontaneously reported to be associated with the monomer by $42 \%$ of the respondents. Previously experienced allergies seemed to predispose the subjects to these irritative reactions. Other finger symptoms, eg, whitening and feelings of numbness, coldness, and pain, were reported by $25 \%$ of the respondents. Students attending the fouryear technical school reported an increasing frequency of finger symptoms as their studies advanced, and in their senior year they reported the same frequency of occurrence as the qualified dental technicians.
\end{abstract}

Key terms: acrylic resins, contact dermatitis, fingers, questionnaire.

Dental technicians and their technical aids daily handle many chemicals with their bare hands. Because of this activity and the need to wash their hands frequently, local dermatological problems are common. One of the most used chemicals is the monomer methyl methacrylate. There are many reports on the adverse effects of this chemical $(2,8,9,10,11,19)$.

Methyl methacrylate is commonly used in a mixture with prepolymerized oligomers to prepare prostheses and orthodontic devices that are finished with the preparer's bare hands to obtain the desired dimensions before the final hardening. In this respect, dental uses of the monomer differ from industrial applications, which do not generally require manual handling of monomer-containing products. Three to five percent of autopolymerizing repair acrylic, used by both technicians and dentists, is unreacted monomer, while less than $1 \%$ of the polynierized denture base, acrylic of a hot-cure type, is unreacted monomer (18). If the polymerization reaction has been properly carried out, little of the unreacted monomer remains, and no dermal or mucous membrane problems occur in patients $(8,11,15)$, despite claims to the contrary $(6,21)$.

Mechanical processing of polymerized articles by filing or sawing may, however, liberate monomer and fine dust so that irritation occurs (12). The concentration of acrylic monomer in the workroom air has been reported to be below $100 \mathrm{ppm}(4)$, which is

\footnotetext{
1 Odontological Centre Odontoma, Helsinki, Finland.

2 Institute of Occupational Health, Helsinki, Finland.
}

Reprint requests to: Dr R Rajaniemi, Odontological Centre Odontoma, Töölönkatu 30 b, SF-00260 Helsinki, Finland. the hygienic standard applied in the United States. The dermatological problems of exposed workers probably depend mainly on direct contact with monomeric or partially polymerized acrylic. The protective gloves commonly used are not helpful, as the monomer can permeate them, and they may worsen the absorption of the chemical $(16,22)$.

In order to study both the use of the acrylic monomer in dental technology and the possible symptoms associated with different types of work, a questionnaire study was carried out. It was complemented by thorough dermatological and neurophysiological examinations of those technicians reporting current dermatological problems $(7,20)$. The results of the questionnaire study are reported in the present work.

\section{Subjects and methods}

\section{Subjects}

Included in the study were 102 dental technicians who belonged to their trade union in the greater Helsinki area at the time of the study. The union's membership comprises more than $90 \%$ of the persons who have graduated with this degree. Forty persons (39 \%) had also received a postgraduate diploma qualifying them to service customers without dentists' prescriptions. The remainder carried out work prescribed by dentists.

Thus far, 128 technical aids have been schooled in Finland to assist dental technicians in the preparation of gypsum models and acrylic prostheses. They were also included in the study regardless of the fact that some of them might have been employed outside the Helsinki area. 
To gain some idea of the rate of hygienic problems in a population without previous acrylic exposure, we also surveyed the students of the State Institute for Dental Technicians during one academic year. Every other term of the curriculum is spent in dental laboratories, and the alternating terms in the Institute with theoretical study and related laboratory work. This arrangement obviously caused fluctuations in the reporting of problems.

Dental technicians perform various technical chores extending from metal molding to ceramic, gypsum, and acrylic processing. The special technicians prepare removable acrylic prostheses more often than the ordinary technicians because they are allowed to deal directly with clients. The ordinary technicians generally concentrate on the gold, steel, and ceramic work required by dentists. Most technicians perform acrylic processing, but in many laboratories it is the job of auxiliary personnel, who prepare acrylic impression trays and repair prostheses with cold-cure acrylic, all tasks with exposure to monomeric methyl methacrylate.

Table 1. Data on the respondents to the questionnaire on methyl methacrylate effects.

\begin{tabular}{|c|c|c|c|c|c|}
\hline & \multirow[t]{2}{*}{ Number } & \multicolumn{2}{|c|}{$\begin{array}{c}\text { Age } \\
\text { (years) }\end{array}$} & \multicolumn{2}{|c|}{$\begin{array}{l}\text { Length of time } \\
\text { in current } \\
\text { profession } \\
\text { (years) }\end{array}$} \\
\hline & & Mean & Range & Mean & Range \\
\hline \multicolumn{6}{|l|}{$\begin{array}{l}\text { Special } \\
\text { technicians }\end{array}$} \\
\hline $\begin{array}{l}\text { Males } \\
\text { Females }\end{array}$ & $\begin{array}{r}31 \\
3\end{array}$ & $\begin{array}{l}48 \\
39\end{array}$ & $\begin{array}{l}35-58 \\
36-41\end{array}$ & $\begin{array}{l}21 \\
16\end{array}$ & $\begin{array}{l}12-35 \\
12-18\end{array}$ \\
\hline \multicolumn{6}{|l|}{$\begin{array}{l}\text { Ordinary } \\
\text { technicians }\end{array}$} \\
\hline $\begin{array}{l}\text { Males } \\
\text { Females }\end{array}$ & $\begin{array}{r}45 \\
8\end{array}$ & $\begin{array}{l}40 \\
33\end{array}$ & $\begin{array}{l}26-59 \\
24-54\end{array}$ & $\begin{array}{l}15 \\
10\end{array}$ & $\begin{array}{l}2-40 \\
2-23\end{array}$ \\
\hline \multicolumn{6}{|l|}{ Auxiliaries } \\
\hline $\begin{array}{l}\text { Males } \\
\text { Females }\end{array}$ & $\begin{array}{l}49 \\
66\end{array}$ & $\begin{array}{l}27 \\
27\end{array}$ & $\begin{array}{l}17-46 \\
17-46\end{array}$ & $\begin{array}{l}8 \\
6\end{array}$ & $\begin{array}{l}1-16 \\
1-15\end{array}$ \\
\hline \multicolumn{6}{|l|}{ Students } \\
\hline $\begin{array}{l}\text { Males } \\
\text { Females }\end{array}$ & $\begin{array}{l}57 \\
34\end{array}$ & $\begin{array}{l}23 \\
23\end{array}$ & $\begin{array}{l}15-33 \\
18-51\end{array}$ & $\begin{array}{l}3 \\
4\end{array}$ & $\begin{array}{l}0.5-15 \\
0.5-16\end{array}$ \\
\hline
\end{tabular}

Table 2. Participation in tasks with exposure to the monomeric acrylate. ${ }^{a}$

\begin{tabular}{|c|c|c|c|c|c|c|}
\hline \multirow{2}{*}{ Task } & \multicolumn{2}{|c|}{$\begin{array}{l}\text { Techni- } \\
\text { cians }\end{array}$} & \multicolumn{2}{|c|}{$\begin{array}{l}\text { Techni- } \\
\text { cal aids }\end{array}$} & \multicolumn{2}{|c|}{ Total } \\
\hline & $N$ & $\%$ & $\mathrm{~N}$ & $\%$ & $\mathrm{~N}$ & $\%$ \\
\hline \multirow{4}{*}{$\begin{array}{l}\text { Preparation of } \\
\text { impression trays } \\
\text { Repair and preparation } \\
\text { of removable prostheses } \\
\text { Preparation of orth- } \\
\text { odontic devices } \\
\text { Preparation of occlusal } \\
\text { splints }\end{array}$} & 49 & 56 & 89 & 77 & 138 & 68 \\
\hline & 69 & 79 & 98 & 85 & 162 & 80 \\
\hline & 17 & 20 & 32 & 28 & 49 & 24 \\
\hline & 37 & 43 & 40 & 35 & 77 & 38 \\
\hline
\end{tabular}

a Note that the same persons may have participated in more than one or even all of the tasks.
The demographic data and duration of employment in current occupations are presented for those subjects who responded to the questionnaire in table 1 .

\section{Methods}

Multiple choice questionnaires were mailed to all the prospective participants. In the case of nonresponse, two reminders were also sent. The questionnaires were completed by 89 dental technicians $(87 \%)$ and by 116 technical aids $(91 \%)$. Of the 94 students, 91 responded $(97 \%)$. Two dental technicians and one technical aid were excluded from the analysis, as they were not employed in the type of work under study at that time.

The items in the questionnaires included, eg, the daily use of acrylic resins and participation in work with exposure to the unreacted monomer. All dermatological problems were inquired about, and the respondents were asked to locate any hand problems on the palmar or dorsal aspects of a hand printed on the questionnaire. More general hand symptoms were also inquired about; they included, eg, whitening, coldness, numbness, and pain in the fingers. Finally, any history of hypersensitive diseases (asthma, allergic conjunctivitis, rhinitis, and atopic dermatitis) was requested. The respondents were classified into these broad diagnostic categories on the basis of their answers to questions describing typical symptoms and, if appropriate, also the diagnosis in Finnish. In addition, it was specifically asked whether a given diagnosis had been made by a physician. The time of the onset of the symptoms was also requested.

The frequency of complaints reported by the special technicians, the ordinary technicians, the technical aids, and the students were compared. In the case of the first three mentioned groups, each group was compared to the two other groups combined if no statistical differences were found. The students were handled as an individual group in all comparisons. The statistical evaluations were made with the chisquare test, using binomial distributions for determining the limits of expectation.

\section{Results}

According to the questionnaire results the dental technicians and technical aids handled the monomeric methyl methacrylate very frequently; only four of them $(2 \%)$ reported complete nonexposure to it. Daily handling varied from contact with the monomer for less than $1 \mathrm{~h}$ for 83 subjects $(41 \%)$ to contact for $1-3 \mathrm{~h}$ for $97(48 \%)$ and to contact for more than 3 h by $18(9 \%)$. The aids had more contact with acrylic articles than the other subjects; $72 \%$ of them handled such articles more than $1 \mathrm{~h} / \mathrm{d}$ versus $37 \%$ of the rest of the respondents. This greater amount of contact was probably caused by the fact that technical 
Table 3. Occurrence of self-reported dermatitis on the hands of the dental technicians and technical aids.

\begin{tabular}{|c|c|c|c|c|c|c|c|}
\hline \multirow[b]{3}{*}{$\begin{array}{l}\text { Special technicians } \\
\text { Ordinary technicians } \\
\text { Technical aids }\end{array}$} & \multirow{2}{*}{$\begin{array}{l}\text { Total number } \\
\text { of respon- } \\
\text { dents }\end{array}$} & \multicolumn{2}{|c|}{ Current dermatitis } & \multicolumn{2}{|c|}{ Previous dermatitis } & \multicolumn{2}{|c|}{ Total } \\
\hline & & Number & Percent & Number & Percent & Number & Percent \\
\hline & $\begin{array}{r}34 \\
53 \\
115\end{array}$ & $\begin{array}{l}11^{\star \star} \\
8 \\
15\end{array}$ & $\begin{array}{l}32 \\
15 \\
13\end{array}$ & $\begin{array}{c}2 \\
7 \\
26^{*}\end{array}$ & $\begin{array}{r}6 \\
13 \\
23\end{array}$ & $\begin{array}{l}13 \\
15 \\
41\end{array}$ & $\begin{array}{l}38 \\
28 \\
36\end{array}$ \\
\hline $\begin{array}{l}\text { Total } \\
\text { Males } \\
\text { Females }\end{array}$ & $\begin{array}{r}202 \\
125 \\
77\end{array}$ & $\begin{array}{l}34 \\
24 \\
10\end{array}$ & $\begin{array}{l}17 \\
19 \\
13\end{array}$ & $\begin{array}{l}35 \\
18 \\
17\end{array}$ & $\begin{array}{l}17 \\
14 \\
22\end{array}$ & $\begin{array}{l}69 \\
42 \\
27\end{array}$ & $\begin{array}{l}34 \\
34 \\
35\end{array}$ \\
\hline
\end{tabular}

- $p<0.05$, as compared to the special and ordinary technicians combined; "* $p<0.01$, as compared to the ordinary technicians and technical aids combined.

aids are more engaged in the actual preparation of acrylic prostheses and in the repair of used ones with autopolymerizing acrylic resins than technicians are.

Daily monomer contact and spills onto hands were reported by 163 respondents $(81 \%)$. Protective gloves were used during acrylic molding by three persons only, and in other tasks 15 subjects reported using protective gloves. The phases with the most frequent exposure to the monomer included the preparation of individual impression trays, orthodontic devices, and removable prostheses (table 2). At least one of the operations was carried out by 188 persons $(93 \%)$.

Of the respondents, $69(34 \%)$ reported skin problems on their hands, while dermatitis at the time of the study was reported by 34 persons (17\%) (table 3 ). Acrylic allergy was reported to have been diagnosed previously for only four persons $(2 \%)$ ). At the time of the study, the frequency of reported dermal problems was greater among the special technicians than among the ordinary technicians and the technical aids $(\mathrm{p}<0.01)$. Previous dermatitis was, however, reported more frequently by the aids than by the technicians $(p<0.05)$ (table 3$)$. No statistically significant difference was found between the men and the women.

Twenty-nine respondents spontaneously reported that exposure to the acrylic monomer was related to the appearance of dermatitis.

The reported dermatitis occurred on the finger tips, around the finger nails, and between the fingers of 44 of the 65 persons who pointed out the loca-
Table 4. Occurrence of self-reported general symptoms in the fingers of the dental technicians and technical aids. ${ }^{a}$

\begin{tabular}{|c|c|c|c|c|c|c|}
\hline \multirow[t]{2}{*}{ Symptom } & \multicolumn{2}{|c|}{$\begin{array}{l}\text { Special } \\
\text { technicians } \\
(N=34)\end{array}$} & \multicolumn{2}{|c|}{$\begin{array}{l}\text { Ordinary } \\
\text { technicians } \\
(\mathrm{N}=53)\end{array}$} & \multicolumn{2}{|c|}{$\begin{array}{c}\text { Technical } \\
\text { aids } \\
(\mathrm{N}=115)\end{array}$} \\
\hline & $N$ & $\%$ & $N$ & $\%$ & $N$ & $\%$ \\
\hline Coldness & 4 & 12 & 3 & 6 & 13 & 11 \\
\hline Numbness & 7 & 21 & 6 & 11 & 18 & 16 \\
\hline Pricking & 2 & 6 & 6 & 11 & 8 & 7 \\
\hline Whitening & 1 & 3 & 1 & 2 & 4 & 4 \\
\hline Pain & 2 & 6 & 2 & 4 & 4 & 4 \\
\hline \multicolumn{7}{|l|}{$\begin{array}{l}\text { One or more of } \\
\text { the symptoms }\end{array}$} \\
\hline Males & 8 & 26 & 7 & 16 & 9 & 18 \\
\hline Females & 1 & 33 & 3 & 38 & 22 & 33 \\
\hline
\end{tabular}

a The same person may have reported several of the symptoms.

tion of their dermatitis on the printed hand of the questionnaire. Dermatitis on the dorsum of the hand or on the palmar skin was reported by 21 respondents, and dermatitis on both hands by 51 .

The mean duration of self-reported dermatitis was 7 years (from 2 weeks to 40 years), and 14 persons had had it for 5 years or longer. Abatement during holiday periods and reappearance after the resumption of work was reported by $46(67 \%)$ and $42(62 \%)$ persons, respectively.

The other symptoms (whitening and feelings of numbness, coldness, and pain) were reported frequently in the dominantly exposed hand. Fifty persons

Table 5. Occurrence of self-reported dermatitis and general symptoms in the hands of dental technicians and technical aids.

\begin{tabular}{|c|c|c|c|c|c|c|c|}
\hline \multirow[t]{2}{*}{ Task } & \multirow{2}{*}{$\begin{array}{l}\text { Total number } \\
\text { of respon- } \\
\text { dents }\end{array}$} & \multicolumn{2}{|c|}{ Dermatitis } & \multicolumn{2}{|c|}{ Other symptoms } & \multicolumn{2}{|c|}{$\begin{array}{l}\text { Both symptoms } \\
\text { simultaneousiy }\end{array}$} \\
\hline & & Number & Percent & Number & Percent & Number & Percent \\
\hline $\begin{array}{l}\text { Preparation of trays } \\
\text { Preparation of }\end{array}$ & 138 & 49 & 36 & 38 & 28 & $17^{\star}$ & 12 \\
\hline $\begin{array}{l}\text { prostheses } \\
\text { Both tasks } \\
\text { Only other tasks }\end{array}$ & $\begin{array}{l}162 \\
128\end{array}$ & $\begin{array}{l}56 \\
43\end{array}$ & $\begin{array}{l}35 \\
34\end{array}$ & $\begin{array}{l}45^{*} \\
35\end{array}$ & $\begin{array}{l}28 \\
27\end{array}$ & $\begin{array}{l}18 \\
16^{\star}\end{array}$ & $\begin{array}{l}11 \\
12\end{array}$ \\
\hline than those above & 23 & 4 & 17 & 2 & 9 & 1 & 4 \\
\hline
\end{tabular}

a The same persons may prepare both trays and prostheses.

${ }^{*} \mathrm{p}<0.05$, as compared to the rest of the respondents. 
$(25 \%)$ had experienced at least one of these symptoms (table 4). One or more of the symptoms were reported by $19(27 \%)$ of those who reported dermatitis and 31 (22\%) of those without dermatological symptoms. The symptoms were more frequent among the women than among the men $(p<0.02)$.

The preparation of the acrylic impression trays and prostheses expose the workers the most to the monomeric acrylate. Those who participated in these tasks also reported general hand symptoms, especially with a simultaneous occurrence of hand dermatitis, more frequently than the others (table 5).

Seven respondents reported asthma, diagnosed by a physician, within 12 months or earlier. Allergic rhinitis was reported by $63(31 \%)$, and conjunctivitis by $23(11 \%)$. Atopic dermatitis during childhood was reported by 36 respondents. Those with current dermatitis reported atopic skin disease during childhood more often than the others (29 vs $12 \%$, p < $0.01)$. The same applied to allergic conjunctivitis (20 vs $7 \%, \mathrm{p}<0.01$ ) and rhinitis (42 vs $26 \%, \mathrm{p}<$ $0.05)$.

The reporting of dermatological problems was slightly greater among those who handled the monomer daily for more than $1 \mathrm{~h}$ than among those who handled it daily for less than $1 \mathrm{~h}$ ( $37 \mathrm{vs} 30 \%$ ). This relationship applied to the occurrence of other symptoms as well ( 26 vs $22 \%$ ). These differences were not statistically significant.

Table 6. Occurrence of self-reported hand dermatitis and other finger symptoms among students by year of attendance at the State Institute of Dental Technicians.

\begin{tabular}{|c|c|c|c|c|c|}
\hline \multirow{2}{*}{ Year } & \multirow{2}{*}{$\begin{array}{l}\text { Total number } \\
\text { of respondents }\end{array}$} & \multicolumn{2}{|c|}{ Dermatitis } & \multicolumn{2}{|c|}{$\begin{array}{c}\text { General } \\
\text { symptoms }\end{array}$} \\
\hline & & $N$ & $\%$ & $\mathrm{~N}$ & $\%$ \\
\hline First & 26 & - & 0 & 1 & 4 \\
\hline Second & 23 & 4 & 17 & - & 0 \\
\hline Third & 20 & 3 & 15 & 3 & 15 \\
\hline Fourth & 22 & $7^{*}$ & 32 & 4 & 22 \\
\hline Total & 91 & 14 & 15 & 8 & 9 \\
\hline
\end{tabular}

* $p<0.02$, as compared to the rest of the students.
The number of reported episodes of dermatitis increased among dental technicians as the length of time in the current occupation increased. Technical aids, with generally shorter professional experience, did not show this relationship. The calendar age of the exposed showed little relation to the findings.

Students in their senior year had more symptoms than the other students. Hand dermatitis, especially, had occurred statistically significantly ( $p<0.02$ ) more often in these students than in the others (table 6). In fact, the frequency approached that of the qualified technicians and technical aids combined. Fifteen male students $(26 \%)$ and 12 female students $(35 \%)$ reported having had atopic skin disease; these numbers were less than the respective figures of the technicians (table 7).

\section{Discussion}

This study revealed that the technical trades in odontology have a relatively high risk of dermatological problems. The reported rate of current dermatitis $(17 \%)$ or of previous dermatitis $(17 \%)$ was considerably higher than that $(2.3 \%)$ reported for the general population in south Sweden (1). However, the detected frequency is comparable to the figures reported for general hospital staff, for whom current disease was reported in $8 \%$ and previous occurrence in $36 \%$ (13). The participants in the latter study were engaged in cleaning and service activities or were practical or staff nurses who were obliged to wash their hands frequently. Like dental workers, they could not wear protective gloves at all times, as most chores required manual dexterity.

The dental technicians even reported dissolution of the gloves in the monomeric acrylate. This phenomenon might have had some influence on the high proportion of the dental workers who could associate the occurrence of their symptoms with the use of the monomer. The repair resins seemed to be especially harmful in this respect.

Table 7. Occurrence of self-reported atopic symptoms among dental technicians and technical aids combined and among students with respect to self-reported dermatitis.

\begin{tabular}{|c|c|c|c|c|c|c|c|c|}
\hline \multirow{3}{*}{ Symptom } & \multicolumn{4}{|c|}{ Dental technicians and technical aids } & \multicolumn{4}{|c|}{ Students } \\
\hline & \multicolumn{2}{|c|}{$\begin{array}{l}\text { Without dermatitis } \\
\qquad(N=133)\end{array}$} & \multicolumn{2}{|c|}{$\begin{array}{l}\text { With dermatitis } \\
\qquad(N=69)\end{array}$} & \multicolumn{2}{|c|}{$\begin{array}{l}\text { Without dermatitis } \\
\qquad(\mathrm{N}=77)\end{array}$} & \multicolumn{2}{|c|}{$\begin{array}{l}\text { With dermatitis } \\
\qquad(N=14)\end{array}$} \\
\hline & Number & Percent & Number & Percent & Number & Percent & Number & Percent \\
\hline $\begin{array}{l}\text { Asthma } \\
\text { Allergic rhinitis } \\
\text { Allergic conjunctivitis } \\
\text { Atopic type of dermatitis }\end{array}$ & $\begin{array}{r}4 \\
34 \\
9 \\
16\end{array}$ & $\begin{array}{r}3 \\
26 \\
7 \\
12 \\
\end{array}$ & $\begin{array}{l}3 \\
29^{*} \\
14^{* *} \\
20^{* *}\end{array}$ & $\begin{array}{r}4 \\
42 \\
20 \\
29 \\
\end{array}$ & $\begin{array}{r}1 \\
10 \\
3 \\
12 \\
\end{array}$ & $\begin{array}{r}1 \\
13 \\
4 \\
16 \\
\end{array}$ & $\begin{array}{l}- \\
2 \\
2 \\
4\end{array}$ & $\begin{array}{r}0 \\
14 \\
14 \\
29 \\
\end{array}$ \\
\hline $\begin{array}{l}\text { Total } \\
\text { Males } \\
\text { Females }\end{array}$ & $\begin{array}{l}59 \\
33 \\
26\end{array}$ & $\begin{array}{l}44 \\
40 \\
51\end{array}$ & $\begin{array}{l}27 \\
13 \\
14\end{array}$ & $\begin{array}{l}39 \\
31 \\
52\end{array}$ & $\begin{array}{l}21 \\
11 \\
10\end{array}$ & $\begin{array}{l}27 \\
22 \\
36\end{array}$ & $\begin{array}{l}6 \\
4 \\
2\end{array}$ & $\begin{array}{l}43 \\
50 \\
33\end{array}$ \\
\hline
\end{tabular}

- $p<0.05$, as compared to technicians and aids without the complaint: $" p<0.01$, as compared to technicians and aids without the complaint. 
Hypersensitivity to acrylic monomers seems to be a serious consequence of exposure $(2,5,14,23)$. However, acrylic allergy had been diagnosed in only $2 \%$ of the respondents in this study. In the clinical study, no new allergies were found (7). The symptoms of nonallergic dermatitis caused by methyl methacrylate seem to be rather painless, as surprisingly small numbers had sought medical advice and treatment for their skin problems.

The occurrence of whitening of the fingers and feelings of coldness, numbness, and pain is not surprising, as similar symptoms have been reported by orthopedic surgeons in conjunction with dermatitis, even after the skin lesions had healed (10). The paresthetic symptoms may point to effects on the sensory nerves. A direct neurotoxic action is possible, as methyl methacrylate is absorbed through the skin and is known to affect the myelinated nerve function (3). In the clinical neurophysiological study of 20 dental technicians who reported symptoms at the time of the study, disturbances in the conduction velocities of some nerves were found to be significantly more common than among unexposed referents (20).

Previous atopic symptoms were reported by $43 \%$ of the subjects; this percentage is high in comparison to that of the general Finnish population (17). In the present study persons with reported skin disease during childhood or with allergic conjunctivitis or rhinitis also reported a higher rate of acrylate-associated dermal problems than the other subjects. This finding applied to both the students and the qualified technicians, and it may indicate that these diseases can predispose persons to the dermatological effects caused by methyl methacrylate. It seems therefore that acrylate exposure effects are comparable with other irritant exposures in this respect (13). A policy not to accept persons with allergic diseases as students in the State Institute for Dental Technicians had already been adopted before this study, and this policy probably explains the smaller frequency of these symptoms among the students studied.

Acrylates constitute a versatile group of monomers for prosthetic dentistry, and it is unlikely that their role will diminish in the future. Although the population in this study was not large, it was not biased, as virtually all members of the profession in a particular economic area were contacted. The same applies to the students. Because of the widespread use of methyl methacrylate, no relevant reference population without this specific exposure could be formed. However, a rough relationship to the contact time was established among the technicians. In addition, the frequency of complaints increased among students according to seniority.

Our study indicates that the use of the monomer methyl methacrylate poses an occupational hazard among dental technicians, and, importantly enough, most of the technicians studied clinically asserted ignorance of this hazard. Most of them reported relief of dermal problems after they adopted better work practices and stricter skin care.

\section{Acknowledgments}

We thank Dr E Puro, the former dean of the State Institute for Dental Technicians in Helsinki, for his support and endorsement of our study.

\section{References}

1. Agrup G. Hand eczema and other hand dermatoses in South Sweden. Acta Derm Venereol 49 (1969): suppl $61,18$.

2. Allardice JT. Dermatitis due to an acrylic resin sealer. Trans St John's Hosp Dermatol Soc 53 (1967) 86-89.

3. Böhling HG, Borchard U, Drouin H. Monomeric methylmethacrylate acts on desheathed myelinated nerve and on node of Ranvier. Arch Toxicol 38 (1977) 307.

4. Brune D, Beltesbrekke H. Levels of methylmethacrylate, formaldehyde, and asbestos in dental workroom air. Scand J Dent Res 89 (1981) 113-116.

5. Chung $\mathrm{CW}$, Giles AL. Sensitization potentials of methyl, ethyl, and n-butyl methacrylates and mutual cross-sensitivity in guinea pigs. J Invest Dermatol 68 (1977) 187-190.

6. Crissey JT. Stomatitis, dermatitis, and denture materials. Arch Dermatol 92 (1965) 45-48.

7. Estlander T, Rajaniemi R, Jolanki R. Hand dermatitis in dental technicians. Contact Dermatitis 10 (1984) $201-205$.

8. Fisher AA. Allergic sensitization of skin and oral mucosa to acrylic denture materials. J Am Med Assoc 156 (1954) $238-242$.

9. Fisher AA, Franks A, Glick H. Allergic sensitization of the skin and nails to acrylic plastic nails. J Allergy 28 (1957) 84-88.

10. Fries IB, Fisher AA, Salvati EA. Contact dermatitis in surgeons from methylmethacrylate bone cement. J Bone Jt Surg 57A (1975) 547-549.

11. Guill MA, Odom RB. Hearing aid dermatitis. Arch Dermatol 114 (1978) 1050-1051.

12. Harris DK. Health problems in the manufacture and use of plastics. Br J Ind Med 10 (1953) 255-267.

13. Lammintausta K. Hand dermatitis in different hospital workers who perform wet work. Dermatosen Beruf Umwelt 31 (1983) 14-19.

14. Nyquist G. Sensitivity to methyl methacrylate. Trans $\mathbf{R}$ School Dent (Stockholm and Umeå) 1 (1958) 36-51.

15. Nyquist G, Koch G, Magnusson B. Contact allergy to medicaments and materials used in dentistry (III). Odontol Revy 23 (1972) 197-204.

16. Pegum JS, Medhurst FA. Contact dermatitis from penetration of rubber gloves by acrylic monomer. $\mathrm{Br}$ Med J 2 (1971) 141-143.

17. Peltonen L. Atopia ja nikkeliallergia. University of Turku, Turku 1979. (Doctoral dissertation).

18. Ruyter IE. Methacrylate-based polymeric dental materials: Conversion and related properties. Summary and review. Acta Odontol Scand 40 (1982) 359-376.

19. Rycroft RJG. Contact dermatitis from acrylic compounds: Review article. Br J Dermatol 96 (1977) $685-687$.

20. Seppäläinen AM, Rajaniemi R. Local neurotoxicity of methyl methacrylate among dental technicians. Am J Ind Med 5 (1984) 471-477. 
21. Stungis TE, Fink JN. Hypersensitivity to acrylic resin. J Prosthet Dent 22 (1969) 425-428.

22. Waegemaekers TH, Seutter E, den Arend JA, Malten KE. Permeability of surgeons' gloves for methylmethacrylate. Acta Orthop Scand 6 (1983) 790-795.

23. van der Walle HB, Klecak G, Geleick H, Bensink T. Received for publication: 22 August 1984
Sensitizing potential of 14 mono(meth)acrylates in the guinea pig. Contact Dermatitis 8 (1982) 223-235. 